\title{
FENOMENA DAN PERSPEKTIF KEPEMIMPINAN PENDIDIKAN
}

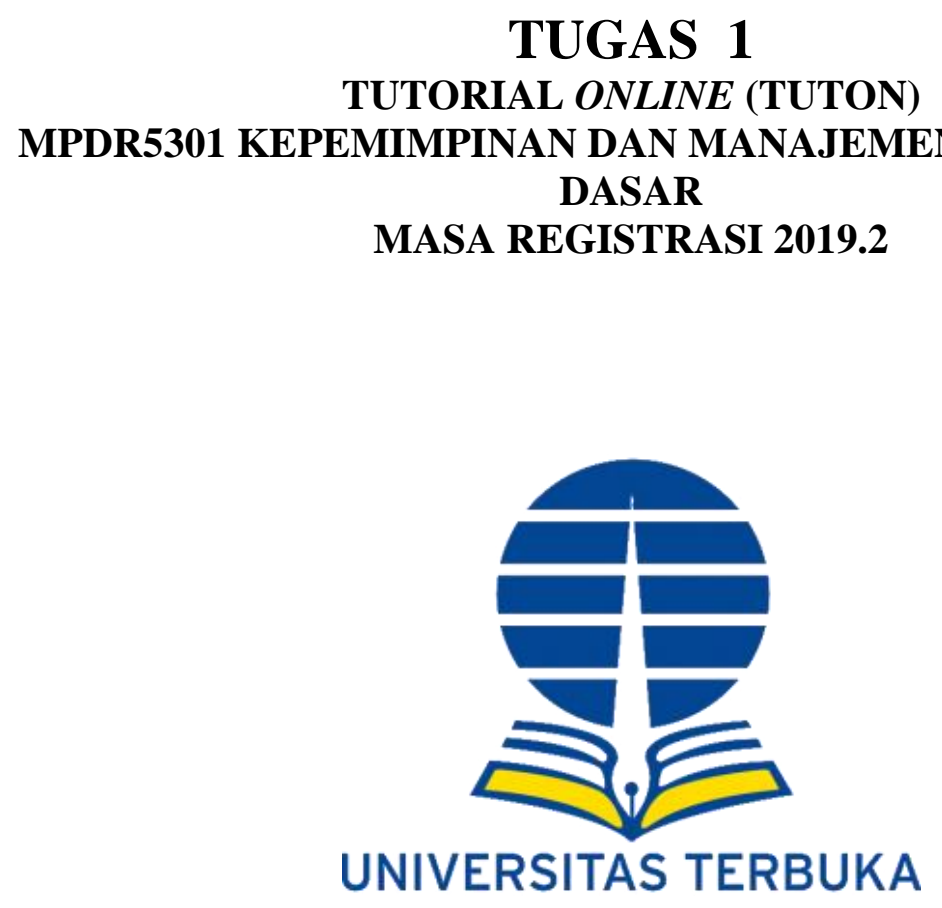

OLEH:

ARIS AGUSTONI

NIM : 530017472

\section{PROGRAM PASCASARJANA UNIVERSITAS TERBUKA




\section{BAB I \\ PENDAHULUAN}

\section{Latar Belakang}

Sumiati Kepala Sekolah Teladan Kota Depok "Apabila bersungguh-sungguh, maka Allah SWT pasti akan memberikan jalan keberhasilan, Man Iadda VI/a[ada" ltulah mote hidup Sumiati, KepaJa Sekolah SD Islam Dian Didaktika. Atas kerja keras dan usahanya dalam mendorong kernajuan prestasi siswa dan sekolah yang dipimpinnya, Sumiati terpilih menjadi kepala sekolah teladan Kota Depok tahun 2013. Ia turut menghantarkan SD Islam Dian Didaktika meraih Best Practice pendidikan karakter tingkat asional oleh Pusat Kurikulum Kemendiknas tahun 2010. Tak hanya itu, saat Ujian Nasional (UN), nilai siswa Sumiati selalu berada di atas angka 8 serta menyabet predikat juara I lomba Sekolah Sehat Kota Depok. "Saya sangat bersyukur, Berkat kerja keras dan kesungguhan dalam berusaha, akhirnya kami membuahkan hasil. Saya juga mengucapkan terima kasih kepada segcnap pengurus Yayasan Dian Didaktika, para guru dan karyawan atas dukungan serta doa sehingga berhasil menjadi juara" imbuh Sumiati yang sebelumnya juga terpilih sebagai kepala sekolah teladan tingkat Kecamatan Cinere. Ibu tiga anak itu mengatakan, ia mengawali karir sebagai guru pada tahun 1999 di Sekolah Dasar Al-Muhajirin Depok 1. Kemudian akhir tahun 1999, ia pindah mengajar di SDI Dian Didaktika. Perempuan kelahiran Jakarta, 28 Agustus 1972 ini pun mengaiar di kelas 2 dan kelas 3 sebagai guru kelas dan di kelas 6 sebagai guru mata pelajaran IPA. Ia pun senantiasa mengantarkan siswanya bersiap menempuh UN. Atas ketekunan dan kesabarannya, Sumiati semakin disukai siswanya, Terutama saat menyampaikan pelajaran. Sumiati juga dikenal sosok bersahabat dengan siswanya, sehingga membuat mereka nyaman dan semangat untuk meraih sukses. Tak ayal, prestasi demi prestasi pun diraihnya. Berkat keberhasilannya dalam mendidik siswa, maka tahun 2009 Sumiati diangkat menjadi kepala sekolah. Hal itu pun, menambah motivasi Sumiati untuk terus memberikan yang terbaik bagi peserta didik dan lembaga ternpatnya bekerja.

"Bekerja sebagai pendidik berarti ikut mempersiapkan masa depan anak-anak dan sekaligus masa depan bangsa ini," tutur perempuan Iulusan S1 FMIPA IKIP Jakarta itu. Di kalangan 
sesama guru, Sumiati dikenal sebagai sosok yang senang belajar, kreatif visioner, berani, tegas tetapi sekaligus rendah hati dan bersahabat. Hubungan yang baik dengan para guru, kedekatan dengan siswa, dukungan dan kepercayaan dari Yayasan Dian Didaktika serta orangtua siswa jadi modal besar baginya untuk mendulang prestasi. "Lingkungan sekolah tempat saya mengajar sangat kondusif. Hal ini yang mendukung saya untuk terus memberikan layanan pembelajaran terbaik bagi para siswa untuk mendapatkan prestasi," paparnya Sumiati menambahkan, keberhasilannya itu juga tak lepas dari dukungan Dinas Pendidikan Kota Depok, Dukungan tersebut ia rasakan sangat membantu untuk berkompetisi di tingkat provinsi Jawa Barat. Setelah berhasil menjadi juara 1 sebagai kepala sekolah teladan tingkat kota Depok, Sumiati mewakili Kota Depok mengikuti kompetisi kepala sekolah teladan tingkat Propinsi Iawa Barat. Sumiati berhasil meraih peringkat ke-5 dari 26 peserta tingkat kabupaten/kota di Jawa Barat. Berikut tips yang diberikan Sumiati dalam mengajar dan mengemban tugas sebagai kepala sekolah : a. Kreatif menciptakan lingkungan sekolah maupun kelas sehat dan nyaman bagi siswa untuk belajar dan mengembangkan potensinya dengan optimal. b. Disiplin dan tertib dalam manajemen kelas maupun sekolah c. Terus belajar menciptakan inovasi dalam proses pembelajaran di kelas sehingga para siswa termotivasi untuk berprestasi. d. Menularkan semangat, memfasilitasi dan memberi teladan kepada para guru untuk meningkatkan kompetensinya sehingga dapat terus meningkatkan mutu dan kemajuan sekolah. Sumber: Sumiati Kepala Sekolah Teladan Kota Depok. (2014, januari). Warta Kota Depok. Diambil dari http://www.diandidaktika.sch.id/dd-info/62-teachers-corner/209-sumiati-kepala-sekolahteladan-kota-depok 
BAB II

\section{RUMUSAN MASALAH}

No 1: Jelaskan menurut pemahaman Anda mengenai fenomena pemimpin pendidikan saat ini!

No 2: Berdasarkan kasus di atas, darimanakah terbentuknya perspektif kepemimpinan yang diembannya? Darimanakah asal terbentuknya model kepemimpinan yang berlaku? 


\section{BAB III}

\section{PEMBAHASAN}

No 1: Jelaskan menurut pemahaman Anda mengenai fenomena pemimpin pendidikan saat ini!

Jawab :

Pendidikan merupakan syarat mutlak untuk dapat mencapai suatu kemajuan, dengan pendidikan kita dapat mengimbangi roda perkembangan kemajuan dunia yang akan meninggalkan orang-orang yang tidak berkompeten untuk mengikutinya. Pendidikan berkaitan erat dengan icon-icon pelaku, pendukung dan proses dari pendidikan tersebut. Bila mutu pendidikan hendak diperbaiki, mutu sumber daya manusia (SDM) pendidikan harus diperbaiki terlebih dahulu. Singkatnya, mutu pendidikan amat bergantung pada SDM pendidikan dan proses dari pendidikan tersebut. Mutu SDM pendidikan amat besar pengaruhnya terhadap mutu dari pendidikan itu sendiri.

Berdasarkan pemikiran di atas, pendidikan sebagai ujung tombak "penghasil SDM" mengemban tugas yang penting dan sangat strategis. Sehubungan dengan itu, keberadaan seorang pemimpin pendidikan adalah sebagai orang yang memegang peranan kunci (key position) dalam rangka mencapai tujuan di atas. Keberadaan seorang pemimpin dalam dunia pendidikan sangat diperlukan walaupun seringkali sulit untuk memilih dan mendapatkannya. pemimpin pendidikan saat ini dapat dilihat dari peranan pemimpin itu sendiri dimana pemimpin pendidikan merupakan perencana/konseptor, manajer/pelaksana, dan supervisor/penyelia. Sebagai Konseptor/perencana/administrator, maka pemimpin harus memahami betul bahwa perencanaan pendidikan memiliki posisi yang sangat strategis dalam keseluruhan proses pendidikan. Perencanaan pada hakikatnya merupakan kegiatan yang berorientasi ke depan. Sehingga dalam memberikan pendidikan yang bermutu, perencanaan pendidikan harus dirumuskan secara menyeluruh, mulai dari tingkat nasional (makro), departemen/daerah (meso), sampai pada tingkat institusi/sekolah (mikro). Pada tingkat mikro, perencanaan pendidikan diterapkan dalam konteks penyusunan perencanaan sekolah (Mulyono:2008). Dalam penyusunan perencanaan tingkat mikro ini dilakukan dengan pertimbangan-pertimbangan kontekstual, sebagaimana diungkapkan Djam'an Satori (2000) dalam Akdon (2007) mencakup: 1. Analisis pihak-pihak yang berkepentingan 
dilakukan dengan memperhatikan aspirasi para guru dan kepala sekolah sebagai stakeholders internal, serta aspirasi siswa dan orang tua, masyarakat, dunia kerja, dan pemerintah sebagai stakeholders eksternal. 2. Perumusan visi, misi, dan tujuan pengembangan sekolah merefleksikan aspirasi para stakeholders, dimana visi, misi, dan tujuan menunjukkan arah dan orientasi pengembangan sekolah seperti yang dikehendaki oleh stakeholders. 3. Perumusan bidang hasil pokok (perluasan dan pemerataan mutu, relevansi, dan efektivitas dan efisiensi pengelolaan) perlu diartikulasikan sebagai rumusan-rumusan yang khas untuk lembaga sekolah tersebut. 4. Analisis posisi mencakup kajian lingkungan internal dan eksternal sekolah.

5. Kajian yang sistematis dan kritis terhadap lingkungan internal dan eksternal lembaga akan melahirkan sejumlah isu-isu strategis sebagai sumber bagi pengembangan sasaran dan program prioritas. 6. Perumusan sasaran pengembangan sekolah menggambarkan nilai-nilai perubahan atau keadaan yang diinginkan oleh lembaga. 7. Perencana perlu merumuskan dengan jelas strategi sasaran-sasaran perencanaan dan pengembangan sekolah, dan melibatkan seluruh komponen pendukung (dalam hal ini stakeholders internal dan stakeholders eksternal) sehingga semua kebutuhan stakeholders ini terakomodir guna tercapainya tujuan yang ingin dicapai. 8. Program pengembangan lembaga sekolah diturunkan dari strategi tindakan untuk mencapai sasaran pengembangan. 9. Pelaksanaan atau implementasi suatu program merupakan fase kritis, sehingga dibutuhkan peran seluruh komponen pendukung pelaksana program secara menyeluruh dan optimal. 10. Pengendalian dan umpan balik dimaksudkan untuk meningkatkan efektivitas pencapaian sasaran dan mengkaji aspek efisiensinya. Sebagai Manajer/pelaksana/pengelola, maka pemimpin pendidikan secara operasional melaksanakan pengelolaan kurikulum, peserta didik, ketenagaan, keuangan, sarana dan prasarana, hubungan sekolah dengan masyarakat, dan ketatausahaan. Semua kegiatan-kegiatan operasional tersebut dilakukan melalui seperangkat prosedur kerja yang meliputi; perencanaan, pengorganisasian, penggerakan, dan pengawasan. Berdasarkan tantangan yang dihadapi lembaga pendidikan di tingkat mikro utamanya, maka pemimpin pendidikan melaksanakan pendekatan-pendekatan baru dalam rangka meningkatkan kapasitas sekolah (Yukl:2009). Dengan demikian dibutuhkan pemimpin pendidikan yang memiliki ketrampilan manajerial yang baik mencakup conceptual skill, human skill, dan technical skill. Menurut Tracey (tanpa tahun) dalam Akhmad Sudrajat (2009), conceptual skill yakni kemampuan seorang pemimpin dalam melihat organisasi sebagai satu kesatuan secara menyeluruh, human 
skill yakni kecakapan pemimpin untuk bekerja secara efektif sebagai anggota kelompok dan untuk menciptakan usaha kerjasama dilingkungan kelompok yang dipimpinnya, sedangkan technical skill yakni kecakapan spesifik tentang proses, prosedur, atau teknikteknik, atau merupakan kecakapan khusus dalam menganalisis hal-hal khusus dan penggunaan fasilitas, peralatan, serta teknik pengetahuan yang spesifik. Dari ketiga skill tersebut, technical skill merupakan karakteristik khas pemimpin pendidikan yang harus didalami

dan dimiliki pemimpin pendidikan di tingkat mikro, yang berdasarkan Peraturan Menteri Pendidikan Nasional nomor 13 tahun 2007, antara lain: 1. Kemampuan menyusun perencanaan sekolah untuk berbagai tingkat perencanaan (yakni perencanaan strategis, perencanaan operasional, perencanaan tahunan, sampai pada perencanaan anggaran belanja). 2. Kemampuan mengembangkan organisasi sekolah sesuai dengan kebutuhan (yakni kebijakan, struktur, deskripsi tugas personalia) 3. Kemampuan memimpin sekolah dalam rangka pendayagunaan sumberdaya sekolah secara optimal (baik sumberdaya manusia, sumberdaya dana, dan sumberdaya sarana prasarana). 4. Kemampuan mengelola perubahan dan pengembangan sekolah menuju organisasi pembelajar yang efektif. 5. Kemampuan menciptakan budaya dan iklim sekolah yang kondusif dan inovatif bagi pembelajaran peserta didik. 6. Kemampuan mengelola guru dan staf dalam rangka pendayagunaan sumberdaya manusia dalam rangka peningkatan mutu secara optimal. 7. Kemampuan mengelola sarana dan prasarana sekolah dalam rangka peningkatan mutu pembelajaran secara optimal. 8. Kemampuan mengelola hubungan sekolah dengan masyarakat dalam rangka pencarian dukungan ide, sumber-sumber belajar, dan pembiayaan pendidikan di sekolah. 9. Kemampuan mengelola peserta didik dalam rangka penerimaan siswa baru, penempatan, dan pengembangan kapasitas siswa secara optimal. 10. Kemampuan mengelola pengembangan kurikulum dan kegiatan pembelajaran secara optimal sesuai dengan arah dan tujuan yang ingin dicapai, dan Kemampuan memonitoring dan mengevaluasi semua program kegiatan yang dilaksanakan guna perbaikan dan peningkatan kualitas. Sebagai Supervisor/penyelia/evaluator, maka sebagai pemimpin pengajaran, pemimpin pendidikan di sekolah berfungsi melakukan pembinaan profesional kepada guru dan tenaga kependidikan. Untuk itu kegiatan pemantauan atau observasi kelas mutlak dilakukan secara teratur sesuai dengan perencanaan dan tujuan yang ingin dicapai, melakukan pertemuan guna memberikan pengarahan teknis kepada guru dan staf dan menawarkan solusi bagi permasalahan pembelajaran yang dialami 
guru (Suryosubroto:2004). Dalam pelaksanaan kegiatan sebagai supervisor (Permendiknas nomor 13 tahun 2007), pimpinan pendidikan diharapkan harus mampu: 1. Merencanakan program supervisi akademik dalam rangka peningkatan profesionalisme guru 2 . Melaksanakan supervisi akademik terhadap guru dengan menggunakan pendekatan teknik supervisi yang tepat 3. Menindaklanjuti hasil supervisi akademik terhadap guru dalam rangka peningkatan profesionalisme guru. Sehingga dalam posisi sebagai pengambil keputusan dan kebijakan di tingkat mikro, pemimpin pendidikan di sekolah; sebagaimana diisyaratkan dalam manajemen pendidikan berbasis sekolah diberi keleluasaan melakukan inovasi-inovasi dan kreatif dalam me-manaj institusinya guna peningkatan mutu institusi yang dipimpinnya.

o 2: Berdasarkan kasus di atas, darimanakah terbentuknya perspektif kepemimpinan yang diembannya? Darimanakah asal terbentuknya model kepemimpinan yang berlaku?

Jawab: Terkait dengan kasus diatas kalau berbicara kepemimpinan bu guru Sumiati maka kita berbicara bu Sumiati sebagai kepala sekolah, dimana Kepala sekolah adalah guru yang diberikan tugas tambahan untuk memimpin suatu sekolah yang diselenggarakan proses belajar-mengajar atau tempat terjadi interaksi antara guru yang memberi pelajaran dan murid yang menerima pelajaran. Kepala sekolah merupakan salah satu komponen pendidikan yang paling berperan dalam meningkatkan kualitas pendidikan. Untuk itu kepala sekolah harus mengetahui tugas-tugas yang harus ia laksankan. Adapun tugas-tugas dari kepala sekolah seperti yang dikemukakan Wahjosumidjo (2002:97) adalah kepala sekolah bekerja dengan dan melalui orang lain. Kepala sekolah adalah seorang mediator atau juru penengah. Dalam lingkungan sekolah sebagai suatu organisasi di dalamnya terdiri dari manusia yang mempunyai latar belakang yang berbeda-beda yang bisa menimbulkan konflik untuk itu kepala sekolah harus jadi penengah dalam konflik tersebut. Kepala sekolah adalah seorang politisi. Kepala sekolah harus dapat membangun hubungan kerja sama melalui pendekatan persuasi dan kesepakatan (compromise). Peran politis kepala sekolah dapat berkembang secara efektif, apabila: (1) dapat dikembangkan prinsip jaringan saling pengertian terhadap kewajiban masing-masing, (2) terbentuknya aliasi atau koalisi, seperti organisasi profesi, OSIS, BP3, dan sebagainya; (3) terciptanya kerjasama (cooperation) dengan berbagai pihak, sehingga aneka macam aktivitas dapat 
dilaksanakan. Kepala sekolah adalah seorang diplomat. Dalam berbagai macam pertemuan kepala sekolah adalah wakil resmi sekolah yang dipimpinnya. Berbicara masalah kinerja dan kompetensi kepala sekolah sebagai sebuah sistem yang kompleks yang terdiri dari sejumlah komponen saling terkait dan terikat, yaitu : kepala sekolah, guru, kurikulum, siswa, bahan ajar, fasilitas, dana, orang tua dan lingkungan. Komponen kepala sekolah merupakan komponen terpenting karena kepala sekolah merupakan salah satu input sekolah yang memiliki tugas dan fungsi paling berpengaruh terhadap keberlangsungan proses pendidikan di sekolah. Desentralisasi dengan kebijakan Manajemen Berbasis Sekolah menuntut seorang kepala sekolah tidak hanya menjadi seorang manajer yang lebih banyak berkosentrasi pada permasalahan anggaran dan persoalan administratif , namun juga dituntut menjadi seorang pemimpin yang mampu menciptakan visi yang terkait dengan sekolah. meminjam istilah Gardner (1986) sebagai manajer pemimpin. dalam menjalankan proses persekolahan. Slamet PH (2002) menyebutkan kompetensi yang wajib dimiliki seorang kepala sekolah untuk dapat menjalankan tugas dan fungsinya secara optimal sebagai berikut : kepala sekolah harus memiliki wawasan ke depan (visi) dan tahu tindakan apa yang harus dilakukan (misi) serta paham benar cara yang akan ditempuh (strategi, memiliki kemampuan pengambilan keputusan dengan terampil, memiliki kemampuan memobilisasi sumberdaya yang ada untuk mencapai tujuan dan mampu menggugah bawahannya untuk melakukan hal-hal penting bagi tujuan sekolahnya. Disamping itu kemampuan untuk membangun partisipasi dari kelompok-kelompok kepentingan sekolah (guru, siswa, orangtua siswa, ahli, dsb.) sehingga setiap keputusan yang diambil merupakan keputusan partisipatif. Kompetensi memainkan peran kunci dalam mempengaruhi keberhasilan kerja, terutama dalam pekerjaan-pekerjaan yang menuntut sungguh-sungguh inisiatif dan inovasi. Kompetensi dipahami berkaitan dengan pentingnya hasrat untuk menguasai orang lain, dan secara lebih luas berkaitan dengan menciptakan peristiwa dan bukan sekedar menanti secara pasif, hasrat ini disebut motif kompetensi. Dalam diri orang dewasa motif kompetensi ini sangat mungkin muncul sebagai suatu keinginan untuk menguasai pekerjaan dan jenjang profesional. Pengertian sederhana yang mendasar dari kompetensi adalah kemampuan atau kecakapan (Syah,2000:229). Kemampuan atau kecakapan yang dimaksudkan dalam kompetensi itu menunjuk kepada satu hal yang menggambarkan kualifikasi atau kemampuan seseorang, baik kemampuan atau kecakapan kualitatif maupun kuantitatif. Ranupandoyo dan Husnan (1995:155) mengidentikan kemampuan dengan ketrampilan kerja yang berbentuk dari pendidikan 
dan latihan serta pengalaman kerja. Keith Davis (dalam Anwar, 2000:67) membedakan kemampuan dengan ketrampilan.

Kompetensi merupakan perpaduan dari penguasaan pengetahuan, ketrampilan, nilai dan sikap yang direfleksikan dalam kebiasaan berfikir dan bertindak pada sebuah tugas/pekerjaan. Kompetensi juga merujuk pada kecakapan seseorang dalam menjalankan tugas dan tanggung-jawab yang diamanatkan kepadanya dengan hasil baik dan piawai/mumpuni (Margono,2003). Adapun Kompetensi Kepala Sekolah adalah sebagai berikut. a. Kompetensi Kepribadian Definisi yang paling sering digunakan dari kepribadian dikemukakan oleh Gordon Allport hampir 60 tahun yang lalu. Ia mengatakan bahwa kepribadian adalah organisasi dinamis pada masing-masing sistem psikofisik yang menentukan penyesuaian unik terhadap lingkungannya. Dalam menjalankan tugas menejerial kepala sekolah dituntut memiliki kompetensi kepribadian, kompetensi ini menuntut kepala sekolah memiliki (1) integritas kepribadian yang kuat, yang dalam hal ini ditandai dengan konsisten dalam berfikir, berkomitmen, tegas, disiplin dalam menjalankan tugas, (2) memiliki keinginan yang kuat dalam mengembangkan diri sebagai kepala sekolah, dalam hal ini meliputi memiliki rasa keingintahuan yang tinggi terhadap kebijakan, teori, praktik baru, mampu secara mandiri mengembangkan diri sebagai upaya pemenuhan rasa ingin tahu (3) bersikap terbuka dalam melaksanakan tugas, meliputi berkecenderungan selalu ingin menginformasikan secara transparan dan proporsional kepada orang lain mengenai rencana, proses pelaksanaan dan efektifitas program. (4) mampu mengendalikan diri dalam menghadapi masalah dalam pekerjaan (5) memiliki bakat dan minat jabatan sebagai pemimpin. Berdasarkan definisi-definisi di atas dalam yang dimaksud dengan kompetensi kepribadian adalah integritas pribadi yang kuat, berkeinginan mengembangkan diri, terbuka dan minat dalam menjalankan jabatan sebagai kepala sekolah. b. Kompetensi Manajerial Manajemen atau pengelolaan dapat berarti macam-macam tergantung kepada siapa yang membicarakannya. Ruang lingkup tugas manajerial kepala sekolah meliputi aktivitas sebagai berikut: a) menyusun rencana pengembangan sekolah, b) mengelola program pembelajaran, c) mengelola kesiswaan, d) mengelola sarana dan prasarana, e) mengelola personal sekolah, f) mengelola keuangan sekolah, g) mengelola hubungan sekolah dan masyarakat, h) mengelola administrasi sekolah,

i) mengelola sistem informasi sekolah, j) mengevaluasi program sekolah, dan k) memimpin sekolah (Mulyasa, 2010 : 23) c. Kompetensi Kewirausahaan Kompetensi kewirausahaan dalam adalah kemampuan kepala sekolah dalam mewujudkan aspirasi kehidupan 
mandiri yang dicirikan dengan kepribadian kuat, bermental wirausaha. Sedangkan jika ingin sukses dalam mengembangkan program kewirausahaan di sekolah, maka kepala sekolah, tenaga kependidikan baik guru maupun non guru dan peserta didik harus bisa secara bersama memahami dan mengembangkan sikap kewirausahaan sesuai dengan tugas masing-masing. d. Kompetensi Supervisi Kompetensi supervisi ini dalam hal ini mencakup (1) merencanakan program supervisi akademik dalam rangka peningkatan profesionalisme guru (2) melaksanakan supervisi akademik terhadap guru dengan menggunakan pendekatan dan tehnik supervisi yang tepat (3) menindaklanjuti hasil supervisi baik supervisi akademis maupun supervisi klinis terhadap guru dalam rangka peningkatan profesionalisme guru (Depdiknas, 2007:228). Berdasarkan beberapa pengertian di atas maka yang dimaksud dengan kompetensi supervisi adalah pengetahuan dan kemampuan kepala sekolah dalam merencanakan, melaksanakan, dan menindaklanjuti supervisi dalam upaya meningkatkan kualitas sekolah e. Kompetensi Sosial kompetensi sosial adalah kemampuan seorang kepala sekolah dalam bekerjasama dengan orang lain, peduli sosial dan memiliki kepekaan sosial. Kepala sekolah sebagai pengelola satuan pendidikan (sekolah) bertanggung jawab terhadap efektivitas dan efisiensi penyelenggaraan pendidikan di sekolahnya, melalui peranan-peranan yang dimainkannya. Peranan yang dimainkan kepala sekolah sangatlah kompleks, di antaranya peran kepala sekolah sebagai pemimpin, administrator, manajer, supervisor dan penghubung masyarakat (Atmodiwirio, Soebagio, 1991:60). Dalam perspektif kebijakan pendidikan nasional (Depdiknas, 2006), terdapat tujuh peran utama kepala sekolah yaitu, sebagai a. Kepala Sekolah sebagai Edukator (Pendidik) Kegiatan belajar mengajar merupakan inti dari proses pendidikan dan guru merupakan pelaksana dan pengembang utama kurikulum di sekolah. Kepala sekolah yang menunjukkan komitmen tinggi dan fokus terhadap pengembangan kurikulum dan kegiatan belajar mengajar di sekolahnya tentu saja akan sangat

memperhatikan tingkat kompetensi yang dimiliki gurunya, sekaligus juga akan senantiasa berusaha memfasilitasi dan mendorong agar para guru dapat secara terus menerus meningkatkan kompetensinya, sehingga kegiatan belajar mengajar dapat berjalan efektif dan efisien. b. Kepala Sekolah sebagai Manajer Dalam mengelola tenaga kependidikan, salah satu tugas yang harus dilakukan kepala sekolah adalah melaksanakan kegiatan pemeliharaan dan pengembangan profesi para guru. Dalam hal ini, kepala sekolah seyogyanya dapat memfasilitasi dan memberikan kesempatan yang luas kepada para guru untuk dapat melaksanakan kegiatan pengembangan profesi melalui berbagai kegiatan 
pendidikan dan pelatihan, baik yang dilaksanakan di sekolah, seperti : KKKS/KKG tingkat sekolah, in house training, diskusi profesional dan sebagainya, atau melalui kegiatan pendidikan dan pelatihan di luar sekolah, seperti: kesempatan melanjutkan pendidikan atau mengikuti berbagai kegiatan pelatihan yang diselenggarakan pihak lain. Sebagai manajer, seorang kepala sekolah harus memerankan. Fungsi manajerial kepala sekolah dengan melakukan proses perencanaan, pengorganisasian, mengerakkan dan mengoordinasikan (Nurkolis, 2003:119-121). c. Kepala Sekolah sebagai Administrator Tujuh kegiatan pokok yang harus diemban kepala sekolah yakni merencanakan, mengorganisasi, mengadakan staf mengarahkan/orientasi sasaran, mengkoordinasi, memantau serta menilai/evaluasi. Melalui kegiatan perencanaan terjawablah beberapa pertanyaan: Apa yang akan, apa yang seharusnya dan apa yang sebaiknya? Hal ini tentu berkaitan dengan perencanaan reguler, teknis-opersional dan perencanaan strategis (jangka pendek, jangka menengah dan jangka panjang). Kepala sekolah mulai menggarap bidang sasaran yang mungkin sebelumnya sudah dikaji secara bersama-sama. d. Kepala Sekolah sebagai Supervisor Kepala sekolah mempunyai tugas sebagai supervisor. Kepala sekolah sebagai supervisor dimaksudkan untuk meningkatkan pengawasan dan pengendalian terhadap guru-guru dan personel lain untuk meningkatkan kinerja mereka. Kepala sekolah sebagai supervisor bertugas mengatur seluruh aspek kurikulum yang berlaku di sekolah agar dapat memberikan hasil yang sesuai dengan target yang telah ditentukan. Aspek-aspek kurikulum yang harus dikuasai oleh kepala sekolah sebagai supervisor adalah materi pelajaran, proses belajar mengajar, evaluasi kurikulum, pengelolaan kurikulum, dan pengembangan kurikulum. Tugas dan tanggung jawab merupakan sesuatu hal yang harus dilaksanakan oleh seseorang dalam memangku suatu jabatan. Demikian pula dengan tugas dan tanggung jawab kepala sekolah. Kepala sekolah adalah pemimpin pendidikan yang memiliki peranan sangat besar dalam mengembangkan mutu

pendidikan di sekolah. Berkembangnya semangat kerja, kerjasama yang harmonis, minat terhadap perkembangan pendidikan, suasana kerja yang menyenangkan dan perkembangan mutu profesional di antara para guru, banyak ditentukan oleh kualitas kepemimpinan kepala sekolah. Dengan demikian kepala sekolah adalah salah satu kunci keberhasilan sekolah dalam mencapai tujuannya. Sebagai leader, seorang Kepala Sekolah harus mampu mengerakkan orang lain agar secara sadar dan sukarela melaksanakan kewajibannya secara baik sesuai dengan yang diharapkan pimpinan dalam rangka mencapai tujuan (Nurkolis, 2003:119-121). f. Kepala Sekolah Sebagai Inovator Dalam 
rangka melakukan peran dan fungsinya sebagai innovator, kepala sekolah harus memiliki strategi yang tepat untuk menjalin hubungan yang harmonis dengan lingkungan, mencari gagasan baru, mengintegrasikan setiap kegiatan, memberikan teladan kepada seluruh tenaga kependidikan sekolah, dan mengembangkan model model pembelajaran yang inofatif. Kepala sekolah sebagai inovator akan tercermin dari cara cara ia melakukan pekerjaannya secara konstruktif, kreatif, delegatif, integratif, rasional, objektif, pragmatis, keteladanan g. Kepala Sekolah Sebagai Motivator Sebagai motivator, kepala sekolah harus memiliki strategi yang tepat untuk memberikan motivasi tenaga kependidikan dalam melaksanakan tugas dan fungsinya. Motivasi ini dapat ditumbuhkan melalui pengaturan lingkungan fisik, pengaturan suasana kerja, disiplin, dorongan, penghargaan secara efektif, dan penyediaan berbagai sumber belajar melalui pengembangan Pusat Sumber Belajar (PSB). h. Kepala sekolah sebagai pencipta iklim kerja Budaya dan iklim kerja yang kondusif akan memungkinkan setiap guru lebih termotivasi untuk menunjukkan kinerjanya secara unggul, yang disertai usaha untuk meningkatkan kompetensinya. Oleh karena itu, dalam upaya menciptakan budaya dan iklim kerja yang kondusif, kepala sekolah hendaknya memperhatikan prinsip-prinsip sebagai berikut : (1) para guru akan bekerja lebih giat apabila kegiatan yang dilakukannya menarik dan menyenangkan, (2) tujuan kegiatan perlu disusun dengan dengan jelas dan diinformasikan kepada para guru sehingga mereka mengetahui tujuan dia bekerja, para guru juga dapat dilibatkan dalam penyusunan tujuan tersebut, (3) para guru harus selalu diberitahu tentang dari setiap pekerjaannya, (4) pemberian hadiah lebih baik daripada hukuman, namun sewaktu-waktu hukuman juga diperlukan, (5) usahakan untuk memenuhi kebutuhan sosio-psiko-fisik guru, sehingga memperoleh kepuasan (E. Mulyasa, 2003). i. Kepala sekolah sebagai wirausahawan

Dalam menerapkan prinsip-prinsip kewirausaan dihubungkan dengan peningkatan kompetensi guru, maka kepala sekolah seyogyanya dapat menciptakan pembaharuan, keunggulan komparatif, serta memanfaatkan berbagai peluang. Kepala sekolah dengan sikap kewirausahaan yang kuat akan berani melakukan perubahan-perubahan yang inovatif di sekolahnya, termasuk perubahan dalam hal-hal yang berhubungan dengan proses pembelajaran siswa beserta kompetensi gurunya. 


\section{BAB IV \\ KESIMPULAN}

Berikut tips yang diberikan Sumiati dalam mengajar dan mengemban tugas sebagai kepala sekolah :

a. Kreatif menciptakan lingkungan sekolah maupun kelas sehat dan nyaman bagi siswa untuk belajar dan mengembangkan potensinya dengan optimal.

b. Disiplin dan tertib dalam manajemen kelas maupun sekolah

c. Terus belajar menciptakan inovasi dalam proses pembelajaran di kelas sehingga para siswa termotivasi untuk berprestasi.

d. Menularkan semangat, memfasilitasi dan memberi teladan kepada para guru untuk meningkatkan kompetensinya sehingga dapat terus meningkatkan mutu dan kemajuan sekolah. 


\section{REFERENSI:}

Pamungkas, B., 2008. Akuntabilitas Instansi Pemerintah. Survei Pada Pemerintah Dati II DI Yogyakarta.

Iriyadi, I., Pamungkas, B. and Gunawan, L.G., 2015. Sistem Informasi Akuntansi Dalam Kaitannya Dengan Laporan Biaya Produksi Pada Perusahaan CV Surya Pratama Gemilang. Jurnal Ilmiah Akuntansi Kesatuan, 3(3).

Djanegara, M.S., Nurruzzaman, M. and Kesatuan, D.T.A.M., 2006. ANALISIS NET WORKING CAPITAL DENGAN METODE DAYS OF INVENTORY DAN DAYS OF ACCOUNT RECEIVABLE. Jurnal Ilmiah Kesatuan Nomor, 8(19), p.1.

Djanegara, M.S., 2017. Pengaruh kualitas audit terhadap kualitas laporan keuangan pemerintah daerah. Jurnal Akuntansi, 21(3), pp.461-483.

Mulyana, M., 2010. Manajemen Sumber Daya Manusia (SDM) Ritel Dalam Meningkatkan Kinerja Perusahaan. Jurnal Ilmiah Ranggagading, 10(2).

Mubarak, M.M. and Syarif, R., 2006. Dampak Pelatihan Kerja Terhadap Kualitas Kerja Karyawan. Jurnal Ilmiah Kesatuan Nomor, 8(20), p.2.

Hidayat, L., Mulyana, M. and Effendy, M., 2018. Membangun Kepuasan Mahasiswa Pengguna Laboratorium Komputer. JAS-PT Jurnal Analisis Sistem Pendidikan Tinggi, l(2), pp.93-101.

Mulyana, M., Hidayat, L. and Puspitasari, R., 2019. Mengukur Pengetahuan Investasi Para Mahasiswa Untuk Pengembangan Galeri Investasi Perguruan Tinggi. JAS-PT (Jurnal Analisis Sistem Pendidikan Tinggi Indonesia), 3(1), pp.31-52.

Mariyah, M. and Mulyana, M., 2015. ARTICLE REVIEW OF HUMAN CAPITAL, ECONOMIC STRUCTURE AND GROWTH. Jurnal Dosen STIE Kesatuan.

Nurendah, Y., Mulyana, M. and Muanas, M., 2018. Evaluasi dan Pemetaan Minat Studi Siswa SMA dan SMK di Kota Bogor Pada Program Studi Ekonomi Syariah. JAS-PT (Jurnal Analisis Sistem Pendidikan Tinggi Indonesia), 2(2), pp.83-94. 